Open J. Chem., Vol. 1(2018), Issue 1, pp. 01-11

Website: https://pisrt.org/psr-press/journals/ojc/

ISSN: 2618-0758 (Online) 2618-074X (Print)

http://dx.doi.org/10.30538/psrp-ojc2018.0001

\title{
ESTIMATION OF FEXOFENADINE HCL AND PSEUDOEPHEDRINE HCL BY SPECTROPHOTOMETER AND TLC IN COMBINED TABLET DOSAGE FORM
}

\author{
SAJID MAHMOOD ${ }^{1}$, ZAHEER AHMAD, MUHAMMAD ARSHAD
}

\begin{abstract}
The objective of the present work was to develop and validate of an analytical method for the quantitative determination of Fexo. $\mathrm{HCL}$ and Pseudo. $\mathrm{HCl}$ in a combined tablet dosage form by $U V-V$ is spectrophotometry and TLC. The main problem was to separate the two active ingredient from a single bilayered tablet because both the A.P.I's were soluble in the same solvents. As media selection, distilled water and ethanol $(1: 1)$ were used for Pseudo. $\mathrm{HCl}$ and methanol for Fexo. $\mathrm{HCl}$, in which both the drugs were soluble and stable for a sufficient time. Both drugs were measured at $220 \mathrm{~nm}$ and $247 \mathrm{~nm}$, where they showed maximum absorbance. Beer Lambert's law was obeyed at concentration range 4-14 ppm and 5-30 ppm for Fexo. $\mathrm{HCl}$ and Pseudo $\mathrm{HCl}$ respectively. Fexo. $\mathrm{HCl}(Y=0.0643 x+0.9370)$ was measured with correlation coefficient $r=0.9574$ and Pseudo. $\mathrm{HCl}(Y=0.0843 x+0.0219)$ with correlation coefficient $r=0.9992$. The results of analysis have been validated statistically and recovery studies were carried out as $99.29 \% \pm 0.943$ and $99.29 \% \pm 0.941$ which were close to the assay value $100.1 \% \& 100.6 \%$. Precision of the method was measured which showed results for SD (99.57\% \& 99. $51 \%$ ) and \% RSD (99.53\% \& 99.54). The proposed method may be suitably applied for the analysis of Fexo. $\mathrm{HCl}$ and Pseudo. $\mathrm{HCl}$ in tablet pharmaceutical formulation for routine analysis.
\end{abstract}

Key words and phrases: Fexofenadine; Pseudoephedrine; Validation; Spectrophotometer; Nasal decongestant; Water-Ethanol.

Received 09-7-2018. Revised 12-8-2018. Accepted 12-9-2018

1 Corresponding Author

(C) 2018 Sajid Mahmood, Zaheer Ahmed, Muhammad Arshad. This is an open access article distributed under the Creative Commons Attribution License, which permits unrestricted use, distribution, and reproduction in any medium, provided the original work is properly cited. 


\section{Introduction}

Pseudoephedrine (Figure 1) is the most popular active nasal decongestant due to its effectiveness and relatively mild side effects [1. In recent years, it has become increasingly difficult to obtain pseudoephedrine in many states because of its use as a precursor for the illegal drug N-methyl amphetamine (also known under various names including crystal meth, meth ice, etc.) [2]. Fexofenadine, (Figure 2) 2-[4-(1-hydroxy-4-4-[hydroxyl (biphenyl) methyl] piperidin-1-yl butyl) phenyl]-2-methylpropanoic acid is a highly selective peripheral histamine H1 receptor antagonist used in the treatment of allergic diseases such as allergic rhinitis and chronic urticarial.

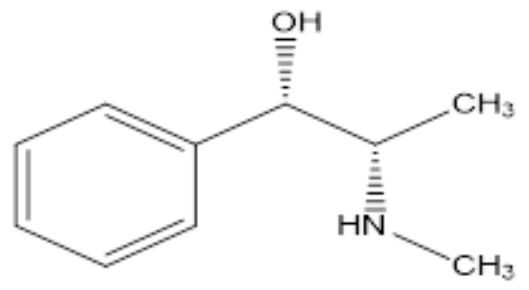

Figure 1. Pseudoephedrine

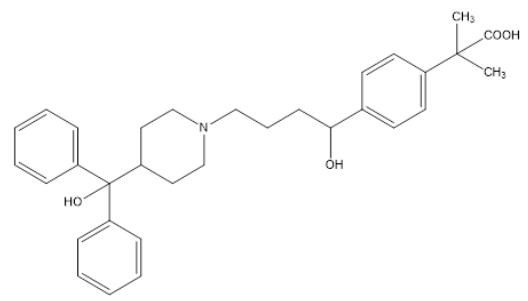

Figure 2. Fexofenadine

Fexofenadine is the active derivative of the antihistamine terfenadine, with no anti-cholinergic or alpha 1-adernergic receptor-blocking effects and without severe cardiac side effects of terfenadine [3, 4.

In literature survey many analytical methods have been reported for the estimating of individual Pseudoephedrine hydrochloride [5, 6, few HPLC assay and dissolution methods have been reported for determination of fexofenadine in pharmaceutical preparation [7]. The estimation of fexofenadine in biological fluids using liquid chromatography with mass spectrometry [8], ionspray tandem mass spectrometry [9, electronspray tandem mass spectrometry [10, UV detection 11, 11 The published method on HPLC was time taking and expensive for the routine analysis of pharmaceutical sectors. However, we have made an attempt to separate both the drugs by Thin Layer Chromatography and estimate it by UV-Visible spectrophotometer which is more reliable and economical. However, no work has so far been carried out for the simultaneous determination of Fexo. $\mathrm{HCl}$ and Pseudo. $\mathrm{HCl}$ in combined tablet dosage form by UV-Vis spectrophotometer and TLC. The aim of the present study is to develop and validate 
a new and economical method for the simultaneous estimation of Fexo. $\mathrm{HCl}$ and Pseudo. $\mathrm{HCl}$ in combine pharmaceutical tablet preparations. The method was validated in compliance with ICH guidelines [12].

\section{Materials and method}

2.1. Chemicals and reagents. The reference standards Fexofenadine $\mathrm{HCl}$ and Pseudoephedrine $\mathrm{HCl}(99.4 \%)$ pure were received as a gift sample from Java Pharmaceutical Kot Lakhpat, Lahore. Organic solvents ethanol and methanol (AR grade) was procured from Merck Chemical. Distilled water was used throughout the study. Sample tablets Fexet-D (Fexo. $\mathrm{HCl}$ and Pseudo. $\mathrm{HCl}$ $60 \mathrm{mg} / 120 \mathrm{mg}$ ) were purchased from local market Lahore, Pakistan.

2.2. Apparatus. TLC tank was used for the separation of both drugs. A single beam UV-Spectrophotometer (Cecil CE 2041, 2000 series) was used for the measurement. Analytical balance (JS-110, Japan) was used to weigh the sample and standard (Fexo. $\mathrm{HCl}$ and Pseudo. $\mathrm{HCl}$ ) material.

2.3. Selection of common solvent. Main criteria for media selection was solubility and stability, i.e. Fexo. $\mathrm{HCl}$ and Pseudo. $\mathrm{HCl}$ should be soluble as well as stable for sufficient time in selected media. Pseudo. $\mathrm{HCl}$ show solubility in distilled water and ethanol $(1: 1)$ and Fexo. $\mathrm{HCl}$ in methanol, respectively. It is economical and hence selected for analysis.

\section{Methodology}

3.1. Thin layer Chromatograph. The grind powder of tablet was dissolved in methanol and filtered the solution with filter paper. The obtained concentrated solution was subjected on precoated silica gel plates. The polarity system $\mathrm{CHCl}_{3} / \mathrm{n}$-Hexane (80:20\%) was developed for TLC. The two A.P.I's were separated which showed the $\mathrm{R}_{f}$ values $\mathbf{0 . 2 5 0 . 0 1}$ and $\mathbf{0 . 6 7 + / - 0 . 0 1}$ for Fexo. $\mathrm{HCl}$ and Pseudo. $\mathrm{HCl}$, respectively. As media selection, distilled water and ethanol (1:1) were used for Pseudo. $\mathrm{HCl}$ and methanol for Fexo.HCl, in which both the drugs were soluble and stable for a sufficien time.

3.2. Preparation of standard stock solutions and calibration curve: An accurately weighed 100mg each Fexo.HCl and Pseudo. $\mathrm{HCl}$ (reference standards) were transferred to two $100 \mathrm{~mL}$ volumetric flask separately and dissolved in methanol and distilled water/ethanol (1:1) individually and make up the volume up to the mark with the same solvent to obtain standard solution having concentration 1000ppm. Magnetic stirrer was used for better dissolution. Further 10ppm dissolution was made by taking $1 \mathrm{~mL}$ from each of the above solution and make up the volume to $100 \mathrm{~mL}$ with methanol and distilled water/ethanol $(1: 1)$.

The working standard solutions $10 \mu \mathrm{g} / \mathrm{mL}$ of Fexo.HCl and Pseudo. $\mathrm{HCl}$ were scanned in the entire UV range 200-400nm to obtain the absorption spectra Fexo. 
$\mathrm{HCl}$ and Pseudo. $\mathrm{HCl}$ showed maximum absorption at $220 \mathrm{~nm}$ and $247 \mathrm{~nm}$, respectively. Further six dilutions from each stock solution were made with their respective solvents in the range $4-14 \mu \mathrm{g} / \mathrm{mL}$ and $5-30 \mu \mathrm{g} / \mathrm{mL}$ for Fexo. $\mathrm{HCl}$ and Pseudo.HCl ,respectively. The absorbance of resulting solutions were measured at respective $\lambda_{\max }$ and plotted a calibration curve against concentration to get the linearity and regression equation as shown in Figures 3 and 4.

3.3. Application of the Proposed Procedure for the Determination in Tablets. The proposed method was applied to determine the concentration of active drug in tablets dosage form. Twenty tablets were weighed and crushed to fine powder, drug equivalent to $60 \mathrm{mg}$ and $120 \mathrm{mg}$ Fexo. $\mathrm{HCl}$ and Pseudo. $\mathrm{HCl}$ was weighed and taken in $100 \mathrm{~mL}$ volumetric flask and make up the volume with methanol and distilled water/ethanol (1:1) respectively. The above solution was filtered by using Whattmann filter paper No. 41. From the above filtrate 10 ppm solution of each active drug was made and subjected for analysis. Analysis procedure was repeated six times with tablet formulation. Aliquot was scanned in the UV range $(200-400 \mathrm{~nm})$. The amount of drug present in the tablets was calculated from the standard graphs as given in Table 1.

3.4. Assay Measurement. The mean assay results of six sample tablets were comparable with claimed value. The obtained results are presented in Table 1 and percentage was found to be $100.1 \%$ and $100.6 \%$ respectively.

TABle 1. Assay Determination of Fexo . $\mathrm{HCl}$ and Pseudo. $\mathrm{HCl}$ from its Tablet

\begin{tabular}{|l|l|l|l|l|}
\hline Sample Tablet & $\lambda_{\max }$ & Label Claimed & $\begin{array}{l}\text { Amount Found } \\
\mathrm{mg} / \text { Tab. }\end{array}$ & Mean \% Assay \\
\hline Fexo .HCl & $220 \mathrm{~nm}$ & $60 \mathrm{mg}$ & $60.1 \mathrm{mg}$ & $100.1 \%$ \\
\hline Pseudo. $\mathrm{HCl}$ & $247 \mathrm{~nm}$ & $120 \mathrm{mg}$ & $120.8 \mathrm{mg}$ & $100.6 \%$ \\
\hline
\end{tabular}

\section{Method Validation}

The developed method was validated by following parameters as provided by $\mathrm{ICH}$.

4.1. Specificity. The sample and the standard spectra were scanned to check the specificity of the method. There was not found any interference of the excipients for the determination of Fexo. $\mathrm{HCl}$ and $\mathrm{Pseudo} . \mathrm{HCl}$ which confirmed the method is highly specified for the estimation of Fexo. $\mathrm{HCl}$ and Pseudo. $\mathrm{HCl}$ in its tablet formulation. 
4.2. Linearity. Various concentrations of the both analyte were made to measure the linearity of the method. The concentration range was 4-14 ppm at $220 \mathrm{~nm}$ for Fexo. $\mathrm{HCl}$ and $5-30 \mathrm{ppm}$ at $247 \mathrm{~nm}$ for Pseudo.HCl. A calibration curve of absorbance versus concentration was plotted. Regression analysis was the confirmation of linearity of this method.

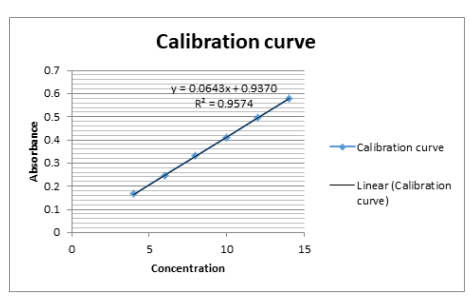

Figure 3. Linearity curve for Fexo. $\mathrm{HCl}$

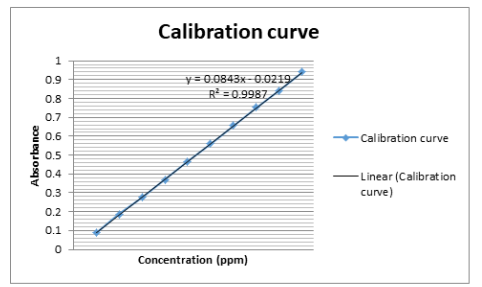

Figure 4. Linearity curve for Pseudo. $\mathrm{HCl}$

4.3. Accuracy. To ensure the accuracy of method, recovery study was performed by preparing six sample solutions of both drugs and added a known amount of active drug to each sample solution then measuring absorbance at $220 \mathrm{~nm}$ and $247 \mathrm{~nm}$ respectively. The \% recovery was calculated along with SD and $\%$ RSD as listed in Table $2 \& 3$

TABLE 2. \% Recovery Result of Fexofenadine $\mathrm{HCl}$

\begin{tabular}{|l|l|l|}
\hline Formulation & Parameters & Results \\
\hline \multirow{3}{*}{ Fexo. HCl } & Regression equation & $Y=0.0643 x+0.9370$ \\
\cline { 2 - 3 } & $\begin{array}{l}\text { Regression } \\
\text { coefficient }\end{array}$ & $R^{2}=0.9574$ \\
\cline { 2 - 3 } & Correlation coefficient & $R=0.9993$ \\
\hline \multirow{3}{*}{ Pseudo. HCl } & Regression equation & $Y=0.0843 x+0.0219$ \\
\cline { 2 - 3 } & Regression coefficient & $R^{2}=0.9987$ \\
\cline { 2 - 3 } & $\begin{array}{l}\text { Correlation } \\
\text { coefficient }\end{array}$ & $R=0.9992$ \\
\hline
\end{tabular}


TABLE 3. \% Recovery Result of Fexofenadine $\mathrm{HCl}$

\begin{tabular}{|l|l|l|}
\hline $\begin{array}{l}\text { Samples after } \\
\text { addition }\end{array}$ & $\begin{array}{l}\text { Absorbance after } \\
\text { addition }\end{array}$ & \% Recovery Assay \\
\hline Sample 1 & 0.717 & $99.88 \%$ \\
\hline Sample 2 & 0.708 & $97.06 \%$ \\
\hline Sample 3 & 0.713 & $99.86 \%$ \\
\hline Sample 4 & 0.721 & $100.2 \%$ \\
\hline Sample 5 & 0.715 & $99.23 \%$ \\
\hline Sample 6 & 0.720 & $98.99 \%$ \\
\hline Mean \% Recovery Assay SD & & $99.29 \% \pm 0.943$ \\
\hline Mean\% Recovery Assay RSD & & $99.29 \% \pm 0.95$ \\
\hline
\end{tabular}

TABLE 4. \% Recovery result of Pseudoephedrine $\mathrm{HCl}$

\begin{tabular}{|l|l|l|}
\hline $\begin{array}{l}\text { Samples after } \\
\text { addition }\end{array}$ & $\begin{array}{l}\text { Absorbance after } \\
\text { addition }\end{array}$ & \% Recovery Assay \\
\hline Sample 1 & 0.178 & $99.88 \%$ \\
\hline Sample 2 & 0.172 & $97.06 \%$ \\
\hline Sample 3 & 0.179 & $99.86 \%$ \\
\hline Sample 4 & 0.176 & $100.2 \%$ \\
\hline Sample 5 & 0.177 & $99.23 \%$ \\
\hline Sample 6 & 0.174 & $98.99 \%$ \\
\hline Mean \% Recovery Assay SD & & $99.29 \% \pm 0.941$ \\
\hline Mean\% Recovery Assay RSD & & $99.29 \% \pm 0.93$ \\
\hline
\end{tabular}

4.4. Precision. Two different tablet solution was taken to measure the precision of method (Tablet-A and Tablet-B) and comparing the value of mean percentage assay with the proposed assay. The mean percentage (\%) assay of the tablets was found to be very close to the proposed assay value $(100.1 \%$ and $100.6 \%$ ) respectively both for Fexo. $\mathrm{HCl}$ and Pseudo.HCl. Hence the assay method was found to be precise.

4.5. Robustness. Robustness was measured by changing the wavelength as $220+1 \mathrm{~nm}$ and $247+1 \mathrm{~nm}(+1 \mathrm{~nm} 221 \mathrm{~nm}, 219 \mathrm{~nm}$ and 248 and $246 \mathrm{~nm})$. The effect of change in wavelength was observed and mean percentage assay was calculated at two different wavelengths and was found to be very close to the proposed assay value (100.1\% and $100.6 \%$ ), thus the robustness parameter was passed by the sample tablets.

4.6. Ruggedness. Ruggedness was determined by analyzing the sample preparations on two different days to check the Ruggedness of the method. The mean percentage $\%$ assay at two consecutive days was found to be very close to the proposed value $(100.1 \% \& 100.6 \%)$ respectively. 
TABLE 5. \% Recovery result of Pseudoephedrine $\mathrm{HCl}$

\begin{tabular}{|l|l|l|l|l|}
\hline $\begin{array}{l}\text { Fexofenadine } \\
\text { HCl }\end{array}$ & $\begin{array}{l}\text { Absorbance } \\
\text { of Tablet-A }\end{array}$ & $\begin{array}{l}\% \text { Assay of } \\
\text { Tablet-A }\end{array}$ & $\begin{array}{l}\text { Absorbance } \\
\text { of Tablet-B }\end{array}$ & $\begin{array}{l}\text { \% Assay of } \\
\text { Tablet-B }\end{array}$ \\
\hline Sample 1 & 0.717 & $99.6 \%$ & 0.716 & $99.26 \%$ \\
\hline Sample 2 & 0.708 & $99.51 \%$ & 0.702 & $99.53 \%$ \\
\hline Sample 3 & 0.713 & $100.2 \%$ & 0.709 & $98.77 \%$ \\
\hline Sample 4 & 0.721 & $99.02 \%$ & 0.714 & $100.11 \%$ \\
\hline Sample 5 & 0.715 & $100.48 \%$ & 0.719 & $99.75 \%$ \\
\hline Sample 6 & 0.720 & $98.65 \%$ & 0.723 & $100.8 \%$ \\
\hline $\begin{array}{l}\text { Mean \% } \\
\text { Recovery Assay } \\
\pm \text { SD }\end{array}$ & - & $\begin{array}{l}99.57 \% \pm \\
0.689\end{array}$ & & $99.53 \% \pm 0.851$ \\
\hline $\begin{array}{l}\text { Mean \% } \\
\text { Recovery Assay } \\
\pm \text { RSD }\end{array}$ & - & $\begin{array}{l}99.57 \% \pm \\
0.691\end{array}$ & & $99.53 \% \pm 0.854$ \\
\hline
\end{tabular}

TABLE 6. \% Assay result of Tablet-A and Tablet -B

\begin{tabular}{|l|l|l|l|l|}
\hline $\begin{array}{l}\text { Pseudoephedrine } \\
\text { HCl }\end{array}$ & $\begin{array}{l}\text { Absorbance } \\
\text { of Tablet-A }\end{array}$ & $\begin{array}{l}\% \text { Assay of } \\
\text { Tablet-A }\end{array}$ & $\begin{array}{l}\text { Absorbance } \\
\text { of Tablet-B }\end{array}$ & $\begin{array}{l}\% \text { Assay of } \\
\text { Tablet-B }\end{array}$ \\
\hline Sample 1 & 0.178 & $99.6 \%$ & 0.180 & $99.26 \%$ \\
\hline Sample 2 & 0.172 & $99.51 \%$ & 0.173 & $99.53 \%$ \\
\hline Sample 3 & 0.179 & $100.2 \%$ & 0.182 & $98.77 \%$ \\
\hline Sample 4 & 0.176 & $99.02 \%$ & 0.184 & $100.11 \%$ \\
\hline Sample 5 & 0.177 & $100.48 \%$ & 0.181 & $99.75 \%$ \\
\hline Sample 6 & 0.174 & $98.65 \%$ & 0.183 & $100.8 \%$ \\
\hline $\begin{array}{l}\text { Mean \% } \\
\text { Recovery Assay } \\
\pm \text { SD }\end{array}$ & - & $99.51 \% \pm$ & & $99.54 \% \pm 0.687$ \\
\hline $\begin{array}{l}\text { Mean \% } \\
\text { Recovery Assay } \\
\pm \text { RSD }\end{array}$ & - & 0.751 & & $99.54 \% \pm 0.696$ \\
\hline
\end{tabular}

4.7. LOD and LOQ. The LOD and LOQ of Fexo.HCl and Pseudo. $\mathrm{HCl}$ in its tablet formulation by proposed method were determined using calibration standards. LOD and LOQ were calculated and the results are shown in Table 11.

\section{Results and Discussions}

Fexofenadine $\mathrm{HCl}$ and Pseudoephedrine $\mathrm{HCl}$ are used as antiallergic and nasal decongestant respectively. The present article deals with the development and 
TABLE 7. \% Assay result of $\lambda_{\max +1}$ and $\lambda_{\max -1}$ Conditions

\begin{tabular}{|l|l|l|l|l|}
\hline $\begin{array}{l}\text { Fexofenadine } \\
\mathrm{HCl}\end{array}$ & \multicolumn{2}{|l|}{$\begin{array}{l}\text { Wavelength plus } \\
\text { condition } \lambda_{\max +1}\end{array}$} & \multicolumn{2}{l|}{$\begin{array}{l}\text { Wavelength subtract } \\
\text { condition } \lambda_{\max -1}\end{array}$} \\
\hline & Absorbance & $\%$ Assay & Absorbance & $\%$ Assay \\
\hline Sample 1 & 0.715 & $100.4 \%$ & 0.719 & $99.26 \%$ \\
\hline Sample 2 & 0.720 & $98.65 \%$ & 0.723 & $99.53 \%$ \\
\hline Sample 3 & 0.713 & $100.2 \%$ & 0.716 & $98.77 \%$ \\
\hline Sample 4 & 0.721 & $99.02 \%$ & 0.702 & $100.11 \%$ \\
\hline Sample 5 & 0.708 & $99.5 \%$ & 0.714 & $99.75 \%$ \\
\hline Sample 6 & 0.717 & $99.6 \%$ & 0.709 & $100.8 \%$ \\
\hline $\begin{array}{l}\text { Mean \% } \\
\text { Recovery Assay } \\
\pm \text { SD }\end{array}$ & - & $99.34 \% \pm$ & & $99.43 \% \pm 0.913$ \\
\hline $\begin{array}{l}\text { Mean \% } \\
\text { Recovery Assay } \\
\pm \text { \%RSD }\end{array}$ & - & 0.836 & & $99.43 \% \pm 0.915$ \\
\hline
\end{tabular}

TABle 8. \% Assay result of $\lambda_{\max +1}$ and $\lambda_{\max -1}$ Conditions

\begin{tabular}{|l|l|l|l|l|}
\hline $\begin{array}{l}\text { Pseudoephedrine } \\
\text { HCl }\end{array}$ & \multicolumn{2}{|l|}{$\begin{array}{l}\text { Wavelength plus } \\
\text { condition } \lambda_{\max +1}\end{array}$} & \multicolumn{2}{l|}{$\begin{array}{l}\text { Wavelength subtract } \\
\text { condition } \lambda_{\max -1}\end{array}$} \\
\hline & Absorbance & $\%$ Assay & Absorbance & $\%$ Assay \\
\hline Sample 1 & 0.178 & $99.60 \%$ & 0.176 & $99.02 \%$ \\
\hline Sample 2 & 0.172 & $99.51 \%$ & 0.177 & $100.48 \%$ \\
\hline Sample 3 & 0.179 & $100.2 \%$ & 0.174 & $98.65 \%$ \\
\hline Sample 4 & 0.180 & $99.26 \%$ & 0.184 & $100.11 \%$ \\
\hline Sample 5 & 0.173 & $100.53 \%$ & 0.181 & $99.75 \%$ \\
\hline Sample 6 & 0.182 & $98.77 \%$ & 0.183 & $100.8 \%$ \\
\hline $\begin{array}{l}\text { Mean \% } \\
\text { Recovery Assay } \\
\pm \text { SD }\end{array}$ & - & $99.34 \% \pm$ & & $99.48 \% \pm 0.911$ \\
\hline $\begin{array}{l}\text { Mean \% } \\
\text { Recovery Assay } \\
\pm \% \text { RSD }\end{array}$ & - & 0.836 & & \\
\hline
\end{tabular}

validation of a new and an economical method for the simultaneous determination of Fexo. $\mathrm{HCl}$ and Pseudo. $\mathrm{HCl}$ in combined tablet dosage form by UV-Vis Spectrophotometer and TLC. The two drugs are present combine in the ratio of $(1: 2)$ which poses a problem in their assay determination. The main problem was to separate the two active ingredients from a single bilayered tablet because both the A.P.I's were soluble in the same solvents. The published method was carried 
TABle 9. \% Assay result of two different days say Day -1 and Day

\begin{tabular}{|l|l|l|l|l|}
\hline Samples & \multicolumn{3}{|l|}{ Day-1 } & Day-2 \\
\hline & Absorbance & \% Assay & Absorbance & $\%$ Assay \\
\hline Sample 1 & 0.715 & $100.04 \%$ & 0.721 & $99.02 \%$ \\
\hline Sample 2 & 0.719 & $99.75 \%$ & 0.702 & $99.53 \%$ \\
\hline Sample 3 & 0.723 & $100.8 \%$ & 0.717 & $99.6 \%$ \\
\hline Sample 4 & 0.713 & $100.2 \%$ & 0.714 & $100.11 \%$ \\
\hline Sample 5 & 0.720 & $98.65 \%$ & 0.709 & $98.75 \%$ \\
\hline Sample 6 & 0.716 & $99.26 \%$ & 0.708 & $99.5 \%$ \\
\hline $\begin{array}{l}\text { Mean \% } \\
\text { Recovery Assay } \\
\pm \text { SD }\end{array}$ & - & $99.39 \% \pm$ & & $99.78 \% \pm 0.0968$ \\
\hline $\begin{array}{l}\text { Mean \% } \\
\text { Recovery Assay } \\
\pm \text { \%RSD }\end{array}$ & - & 0.763 & & $9.39 \% \pm$ \\
\hline
\end{tabular}

TABLE 10. \% Assay result of two different days say Day -1 and Day

\begin{tabular}{|l|l|l|l|l|}
\hline Samples & \multicolumn{3}{|l|}{ Day-1 } & Day-2 \\
\hline & Absorbance & \% Assay & Absorbance & $\%$ Assay \\
\hline Sample 1 & 0.178 & $99.87 \%$ & 0.182 & $98.77 \%$ \\
\hline Sample 2 & 0.173 & $99.38 \%$ & 0.179 & $99.88 \%$ \\
\hline Sample 3 & 0.184 & $100.4 \%$ & 0.183 & $100.03 \%$ \\
\hline Sample 4 & 0.181 & $99.51 \%$ & 0.176 & $99.75 \%$ \\
\hline Sample 5 & 0.177 & $99.02 \%$ & 0.180 & $98.38 \%$ \\
\hline Sample 6 & 0.172 & $98.16 \%$ & 0.174 & $101 \%$ \\
\hline $\begin{array}{l}\text { Mean \% } \\
\text { Recovery Assay } \\
\pm \text { SD }\end{array}$ & - & $99.39 \% \pm$ & & $99.78 \% \pm 0.0968$ \\
\hline $\begin{array}{l}\text { Mean \% } \\
\text { Recovery Assay } \\
\pm \text { \%RDD }\end{array}$ & - & 0.763 & & $9.39 \% \pm$ \\
\hline
\end{tabular}

out on HPLC which is time taking and expensive for the routine analysis of pharmaceutical sectors. However, we have made an attempt to separate both the drugs by TLC and estimate it by UV-Visible spectrophotomtere which is more reliable and economical. The grind powder of tablet was dissolved in methanol and filtered the solution with filter paper. The obtained concentrated solution was subjected on precoated silica gel plates. The polarity system $\mathrm{CHCl} 3 / \mathrm{n}$ Hexane (80:20\%) was developed for TLC. Both the A.P.I's were separated which showed the $\mathrm{Rf}$ values 0.250 .01 and $0.67+/-0.01$ for Fexo. $\mathrm{HCl}$ and Pseudo. $\mathrm{HCl}$, 
TABLE 11. Limit of Detection (LOD) and Limit of Quantitation (LOQ) Results

\begin{tabular}{|l|l|l|}
\hline Samples & Parameters & Results \\
\hline \multirow{4}{*}{ FexofendineHCl } & Slope & 0.0643 \\
\cline { 2 - 3 } & Standard deviation & 0.021 \\
\cline { 2 - 3 } & LOD & $1.077 \mathrm{ppm}$ \\
\cline { 2 - 3 } & LOQ & $3.265 \mathrm{ppm}$ \\
\hline \multirow{4}{*}{ PseuoephdrineHCl } & Slope & 0.0843 \\
\cline { 2 - 3 } & Standard deviation & 0.03 \\
\cline { 2 - 3 } & LOD & $1.174 \mathrm{ppm}$ \\
\cline { 2 - 3 } & LOQ & $3.585 \mathrm{ppm}$ \\
\hline
\end{tabular}

respectively. Visualization of single spot on TLC plate confirmed the purification of compounds. For media selection, distilled water and ethanol (1:1) were used for Pseud. $\mathrm{HCl}$ and methanol was used for Fexo. $\mathrm{HCl}$ in which both the drugs were soluble and stable for sufficient time. Both drugs were measured at $220 \mathrm{~nm}$ and $247 \mathrm{~nm}$ respectively, where they showed maximum absorbance. Beer Lambert's law was obeyed at concentration range 4-14ppm and 5-30 ppm for Fexo. $\mathrm{HCl}$ and Pseudo. $\mathrm{HCl}$, respectively. A linearity curve was calibrated by concentration versus absorbance. Fexo. $\mathrm{HCl}(\mathrm{Y}=0.0643 \mathrm{x}+0.9370)$ was measured with correlation coefficient $\mathrm{r}=0.9574$ and Pseudo. $\mathrm{HCl}(\mathrm{Y}=0.0843 \mathrm{x}+0.0219)$ with correlation coefficient $r=0.9992$. The results of analysis have been validated statistically and recovery studies was carried out as $99.19 \%$ and $99.29 \%$ which were close to the assay value $100.1 \%$ and $100.6 \%$ respectively. Precision of the method was measured which showed results for SD (99.57\%) and \% RSD (99.53 \%), The LOD (1.077ppm) and LOQ (3.265ppm) following ICH guidelines were measured which were found to be within limit. The proposed method was found to be specific, stable, linear, accurate, precise, and reproducible, therefore it can be used for routine quality control analysis of these drugs in either alone or in combined pharmaceutical dosage forms.

\section{Conclusion}

The present method is specific, linear and reproducible thus it can be used for routine quality control analysis of these drugs in either alone or in combined pharmaceutical dosage forms.

\section{Acknowledgement}

The authors are gratified to Jawa Pharmaceutical, 112/10 Industrial area, Kot Lakhpat Lahore, Pakistan for providing a gift sample of Fexofenadine $\mathrm{HCl}$ and Pseudoephedrine $\mathrm{HCl}$ and facilities for the study. We are also thankful to $\mathrm{Mr}$. Baqir Jawa (CEO) Jawa Pharmaceutical for his valuable cooperation during the whole research work. 


\section{Competing Interests}

The authors do not have any competing interests in the manuscript.

\section{REFERENCES}

1. Riley, C. M., \& Rosanske, T. W. (1996). Development and validation of analytical methods (Vol. 3). Elsevier.

2. Surapaneni, S., \& Khalil, S. K. (1994). A sensitive HPLC method for the determination of terfenadine and its metabolite in human plasma. Journal of Liquid Chromatography \& Related Technologies, 17(11), 2419-2428.

3. Coutant, J. E., Westmark, P. A., Nardella, P. A., Walter, S. M., \& Okerholm, R. A. (1991). Determination of terfenadine and terfenadine acid metabolite in plasma using solidphase extraction and high-performance liquid chromatography with fluorescence detection. Journal of Chromatography B: Biomedical Sciences and Applications, 570(1), 139-148.

4. Budavari, S., O'Neil, M. J., Smith, A., \& Heckelman, P. E. (1996). ln; The Merck Index., 12th Edn., Merck and Co. Inc., Whitehouse Station, NJ, 316.

5. Ganjali, M. R., Alipour, A., Riahi, S., Larijani, B., \& Norouzi, P. (2009). Quantitative analysis of pseudoephedrine in formulation by potentiometric membrane sensor; computational investigation. Int. J. Electrochem. Sci, 4, 1262-1276.

6. Zafar, F., Shoaib, M. H., \& Yousuf, R. I. (2011). Development of RP-HPLC method for fexofenadine determination in tablet formulations and development of dissolution method. Pakistan Journal of Pharmacology, 28(1), 43-49.

7. Oliveira, D. C., Weich, A., \& Rolim, C. M. B. (2007). Simple and reliable HPLC analysis of fexofenadine hydrochloride in tablets and its application to dissolution studies. Die Pharmazie-An International Journal of Pharmaceutical Sciences, 62(2), 96-100.

8. Hofmann, U., Seiler, M., Drescher, S., \& Fromm, M. F. (2002). Determination of fexofenadine in human plasma and urine by liquid chromatographymass spectrometry. Journal of Chromatography B, 766(2), 227-233.

9. Flynn, C. A., Alnouti, Y., \& Reed, G. A. (2011). Quantification of the transporter substrate fexofenadine in cell lysates by liquid chromatography/tandem mass spectrometry. Rapid communications in mass spectrometry, 25(16), 2361-2366.

10. Miura, M., Uno, T., Tateishi, T., \& Suzuki, T. (2007). Determination of fexofenadine enantiomers in human plasma with high-performance liquid chromatography. Journal of pharmaceutical and biomedical analysis, 43(2), 741-745.

11. Arayne, M. S., Sultana, N., Shehnaz, H., \& Haider, A. (2011). RP-HPLC method for the quantitative determination of fexofenadine hydrochloride in coated tablets and human serum. Medicinal chemistry research, 20(1), 55-61.

12. ICH Steering Committee. (1996). ICH Q2B Validation of Analytical Procedures: methodology. European Agency for the Evaluation of Medicinal Products, International Commission on Harmonisation, London (CPMP/ICH/281/95).

Sajid Mahmood

Division of Science and Technology, University of Education, Lahore-54590, Pakistan.

e-mail: drsajidue@gmail.com

Zaheer Ahmed

Department of Chemistry, University of Wah, Wah Cantt, Pakistan.

Muhammad Arshad

Institute of Chemistry, University of the Punjab, Lahore, Pakistan. 